\title{
КОМУНІКАТИВНА САМОЕФЕКТИВНІСТЬ МАЙБУТНІХ СУДНОВОДІЇВ ЯК КОНЦЕПТ ПСИХОЛОГО-ПЕДАГОГІЧНИХ ДОСЛІДЖЕНЬ
}

\author{
Дмитрищук Н. В. \\ аспірантка кафедри педагогіки \\ Південноукрайнський національний педагогічний університет імені К. Д. Уиинського \\ вул. Старопортофранківська, 26, Одеса, Україна \\ orcid.org/0000-0003-4876-4790 \\ sergiy2004@gmail.com
}

\begin{abstract}
Ключові слова:
самоефективність, комунікауія, комунікативна ефективність, майбутній судноводій, морський заклад вищзої освіти.
\end{abstract}

Статтю присвячено проблемі вдосконалення рівня професійної підготовки курсантів - майбутніх судноводіїв. Мета статті полягає у висвітленні концептуальних основ феномену «самоефективність» у сучасних психолого-педагогічних дослідженнях, визначенні сутності комунікативної самоефективності майбутніх судноводіїв як важливого детермінанту вдосконалення підготовки курсантів морських закладів вищої освіти до професійної діяльності.

Доведено, що діяльність судноводія являє собою систему сукупності комунікацій, що вимагає від фахівця сформованих соціальнокомунікативних умінь та якостей. Відсутність налагодженої комунікації між береговими службами, членами екіпажу тощо веде до неузгодженості дій команди судна, тому ефективна комунікація є запорукою безаварійної роботи суднової команди й одним із суттєвих показників успішної професійної діяльності судноводія. Комунікативність має неоднозначну ступінь значущості для різних підрозділів плавскладу. Для судноводія спрямованість на спілкування займає вищу позицію, тому комунікація в усіх її проявах має суттєвий вплив на професійну діяльність судноводіїв. Розглянуто феномен «самоефективність» у психолого-педагогічних розвідках вітчизняних і зарубіжних наукових досліджень А. Бандури, Г. Лефрансуа, Скаалвік і Ранкін Б. Циммермана, С. Гончар, О. Вовк та ін. Акцентовано, що характерною особливістю само ефективності $\epsilon$ розуміння того, що вона $є$ проявом упевненості особистості у своїх потенційних можливостях, здатності людини впливати на діяльнісну і соціальну ситуації, відображає уявлення особистості відносно рівня власної ефективності.

Визначено сутність i структурні компоненти комунікативної самоефективності майбутніх судноводіїв у процесі підготовки у морських закладах вищої освіти, які включають рефлексивний (самоідентифікація iз судноводіями як еталонами: професіоналізму, наявність адекватної самооцінки своїх дій у сфері професійного спілкування, усталена рефлексивна позиція); когнітивно-операційний (обізнаність у комунікативній сфері морської професійної діяльності, вміння, навички професійного спілкування); афективно-поведінковий (упевненість у можливості здійснення продуктивної комунікації в професійної діяльності, емоційність, активність, відповідальність, етнокультурна толерантність, здібність до саморегуляції та самопідкріплення). 


\title{
COMMUNICATIVE SELF-EFFICIENCY OF FUTURE NAVIGATORS AS A CONCEPT OF PSYCHOLOGICAL AND PEDAGOGICAL RESEARCH
}

\author{
Dmytryshchuk N. V. \\ Postgraduate Student at the Pedagogy Department \\ South Ukrainian National Pedagogical University named after K. D. Ushynsky \\ Staroportofrankivska str., 26, Odesa, Ukraine \\ orcid.org/0000-0003-4876-4790 \\ sergiy2004@gmail.com
}

Key words: self-efficacy, communication, communicative efficiency, future navigators, maritime institution of higher education.
The article is devoted to the problem of improving the level of cadets professional training. The purpose of the article is to highlight the conceptual foundations of the phenomenon of "self-efficacy" in modern psychological and pedagogical research, to determine the essence of communicative selfefficacy of future navigators as an important determinant of improving the cadets 'training in maritime higher educational institutions for professional activities.

It is proved that the activity of a navigatoris is a system of a set of communications, that requires from the specialist the formed social-communicative skills and qualities. Lack of established communication between shore services, crew members, etc. leads to inconsistencies in the actions of the ship's crew, so effective communication is the key to trouble-free operation of the ship's crew and one of the essential indicators of successful professional activity of the navigator. Communicativeness has an ambiguous degree of significance for different subdivisions of the fleet. For the navigator the focus on communication occupies a higher position, so communication in all its manifestations has a significant impact on the professional activities of navigators.

The phenomenon of "self-efficacy" is determined in psychological and pedagogical scientific publications of domestic and foreign scientists such as A. Bandura, G. Lefrançois, Skaalvik and Rankin B. Zimmerman, S. Gonchar, O. Vovk and others. It is emphasized that a characteristic feature of selfefficacy is the understanding that it is a manifestation of a person's confidence in their potential, a person's ability to influence the activity and social situation, reflects the individual's perception of the level of self-efficacy.

The essence and structural components of future navigators ' communicative self-efficacy in the process of training in maritime institutions of higher education are determined, which include reflexive (self-identification with navigators as standards - professionalism, availability of adequate selfassessment of their actions in professional communication, established reflective position); cognitive-operational (awareness in the communicative sphere of maritime professional activity, skills of professional communication; affective-behavioral (confidence in the possibility of productive communication in professional activities, emotionality, activity, responsibility, ethnocultural tolerance, ability to self-regulation and self-reinforcement).
Постановка проблеми. Глобалізаційні та інтеграційні процеси, що охопили економічне середовище всього світу, потребують використання ефективної транспортної системи, що здійснює надійний зв'язок між різними країнами, континентами для перевезення торгових вантажів, нафти, газу, пасажирів і т. ін. У зв'язку із цим використання морського транспорту у світовому економічному просторі підвищується 3 кожним роком.
Підвищуються вимоги до підготовки компетентних морських фахівців, тому одним зі стратегічних завдань морських ЗВО України стає підготовка професіоналів, що спроможні конкурувати на світовому ринку праці.

Наукові дослідження в контексті підготовки майбутніх судноводіїв до професійної діяльності все більше апелюють до таких іiі знакових характеристик, як комунікативна компетентність, 
комунікативна культура, міжкультурні комунікативні вміння та навички тощо. Більшість учених, практиків у зазначеній сфері (С. Волошинов, О. Діденко, В. Леонтьєв, С. Смірнов, І. Сокол, В. Чернявська та ін.) доводить, що ефективна комунікація $\epsilon$ запорукою безаварійної роботи суднової команди й $є$ одним із суттєвих показників успішної професійної діяльності судноводія. Це ствердження пояснюється тим, що характер та специфіка судноводійної діяльності являє собою систему сукупності комунікацій, що вимагає від фахівця сформованих соціально-комунікативних умінь та якостей. За своєю природою сформована комунікативна самоефективність курсантів сприяє впевненості успішного здійснення майбутньої професійної діяльності. Але можна констатувати, що зазначена проблема ще не знайшла свого належного відображення в науково-методичної літературі і потребує глибокого методологічного опрацювання, що актуалізує іiі у контексті підвищення продуктивності пізнавальної і практичної діяльності курсантів морських закладів вищої освіти України.

Мета статті полягає у висвітленні концептуальних основ феномену «самоефективність» у сучасних психолого-педагогічних дослідженнях, визначенні сутності концепту «комунікативна самоефективність майбутніх судноводіїв» як важливого детермінанту вдосконалення підготовки курсантів морських закладів вищої освіти до професійної діяльності.

Виклад основного матеріалу дослідження. Сучасний судноводій - це професійно-компетентна особистість, яка не лише володіє сукупністю фахових компетенцій (інформаційно-когнітивною, операційно-діяльнісною), а й яскраво вираженою суб' єктною позицією, індивідуальним стилем діяльності, багатим і різнобічним особистісним потенціалом, до якого можна віднести комунікативно-соціальну компетентність, комплекс лідерських якостей, стресостійкість, етнокультурну толерантність, упевненість у собі як професіоналі тощо.

Комунікація в усіх іiі проявах має суттєвий вплив на професійну діяльність судноводіїв. Відсутність налагодженої комунікації між береговими службами або членами екіпажу призводить до неузгодженості дій команди судна. Так, ігнорування або недостатня сформованість у судноводія комунікативних умінь і навичок під час виконання безпосередніх службових обов'язків може призвести до небезпеки судна, пасажирів, екіпажу, втрати вантажу і сприяти серйозній шкоді навколишньому середовищу. У зв'язку із цим точність передачі і прийому судноводіями інформації, адекватність іiі інтерпретації та розуміння сенсу є особливо значущими для професії судноводія.
За своєю специфікою діяльність судноводія пов'язана 3 постійною комунікацією, причому вона носить характер різноплановий і багатогранний, а ії ефективність залежить від великої кількості чинників. Так, у процесі несіння служби моряк зобов'язаний спілкуватися 3 представниками різних організацій: портових служб, судновласників, фрахтователів, крюінгових компаній, класифікаційних товариств, служб контролю руху суден, митними службами, зі страховими агентами, лоцманами, екіпажами інших суден, пасажирами, багатонаціональною командою судна [7].

Згідно з експериментальними дослідженнями, комунікативність має різну ступінь значущості для різних підрозділів плавскладу. Так, для судноводія спрямованість на спілкування займає вищу позицію. Було доведено, що успішні судноводії мають підвищену потребу до ділового спілкування, до взаєморозуміння і співпраці з колегами. A, наприклад, для суднових механіків головне це грамотне обслуговування силових установок судна, однак спрямованість на спілкування і для них має суттєву значущість, відсутність якої може призвести до багатьох проблем [9]. Тому вчені, психологи, педагоги під час підготовки судноводіїв приділять велику увагу формуванню у них комунікативності, толерантності тощо [7].

На нашу думку, суттєву роль у зазначеній підготовці має формування у майбутніх судноводіях комунікативної самоефективності. Відомо, що основою дослідження феномена «самоефективність» виступає соціально-когнітивна теорія А. Бандури, яка розроблялася в 70-х роках XX ст. Сутнісні особливості самоефективності також вивчали Дж. Капаро, Е. Лангер, Дж. Маддукс Дж. Роттер, Д. Сервон, М. Шеєр та ін. Окрім того, самоефективність досліджується в роботах учених України та держав ближнього зарубіжжя (О. Богатирьова, Н. Булинко, О. Вовк, К. Гайдар, М. Гайдар, С. Гончар, Т. Гордєєва, В. Кобець, Т. Левченко, В. Романець, В. Татенко Т. Кремешна, Р. Кричевський, А. Линенко, В. Толочек та ін.), які виявили прямий зв'язок між самоефективністю і такими суттєвими параметрами, як прийняття індивідом рішень, послідовність його дій, а також зв'язок самоефективності і рівня успішності здійснення професійної діяльності фахівця. Характерною особливістю самоефективності $\epsilon$ розуміння, що вона $\epsilon$ проявом упевненості особистості у своїх потенційних можливостях, здатності людини впливати на діяльнісну і соціальну ситуації, відображає уявлення людини про рівень власної ефективності.

На думку А. Бандури, самоефективність - упевненість людини в можливості здійснення певних конкретних дій, тоді як припущення про результат відноситься до того, що він думає про можливі 
наслідки своєї діяльності. Учений уважає, що необхідно розрізняти очікування ефективності (efficacy expectation) й очікування результатів (outcome expectation). Перше - це оцінювання людиною того, що його поведінка призведе до визначених результатів, а друге - це оцінка того, у якому ступені він може вести себе адекватно очікуваному результату [12]. Тобто самоефективність - це переконання індивідуума в тому, що він здатний успішно вибрати таку стратегію своєї поведінки, яка необхідна для досягнення очікуваних результатів.

А. Бандура стверджує, що самоефективність $\epsilon$ центральною детермінантою людської поведінки, яка достатньо точно може передбачати реальну поведінку людини. Психолог уважає, що самоефективність виникає, збільшується або зменшується залежно від приведеного нижче одного 3 чотирьох чинників або від їх комбінації:

- досвіду безпосередньої діяльності (особистісний досвід досягнень);

- непрямого досвіду (досвід, отриманий за допомогою спостереження за іншими);

- думки суспільства (соціальне переконання, висловлена точка зору інших людей);

- фізичного та емоційного стану людини (психологічний (чуттєвий) і фізичний стан: емоційні і фізичні реакції) [13, с. 94].

Таким чином, А. Бандура зазначає, що самоефективність $є$ центральною й однією 3 найважливіших детермінант поведінки людини, яка дає можливість із високою точністю спрогнозувати, як насправді вона проявлятиме себе в різних ситуаціях [12]. Можна зробити висновок, що для судноводія сформованість самоефективності, твердої переконаності, впевненості, що поставлені завдання він може успішно вирішати, має велике значення.

Загальновідомо що пріоритет у дослідженні самоефективності належить американським ученим. Викликає інтерес їхні наукові доробки не лише в парадигмі психології, а й у сфері педагогіки. Так, Мейєр, Тернер і Спенсер [6, с. 324] у дослідженнях самоефективності школярів дійшли висновку, що діти з високим рівнем самоефективності не бояться ризикувати в складних ситуаціях, реагують на невдачу адекватно, без негативу. Марш і Йонг зазначають, що педагогам необхідно розуміти сутність уявлень школярів про власну самоефективність і враховувати ії в здійсненні педагогічної діяльності та міжособистісному спілкуванні [6, с. 322]. Б. Циммерман стверджує, що самоефективність життєво важлива для здатності учня вчитися, що позитивні академічні переконання в самоефективності можуть мотивувати студентів працювати старанніше і вибрати більш складні завдання [17]. До нього приєднуються і А. Вігфілд і Дж.С. Екклс, які вважають, що теорія очікуваної цінності пояснює, що продуктивність і вибір людей залежать від того, наскільки вони цінують завдання, яке треба вирішити. Переконання студента у самоефективності щодо його здатності бути успішним у певній галузі й особистих очікуваннях тісно пов'язані з фактичною успішністю. Дослідники стверджують, що якщо учні цінують заняття, вони докладатимуть більше зусиль і довше займатимуться цими заняттями. При цьому цінність, що надається діяльності та їх очікуванням щодо їх здібностей, залежить від емоційних спогадів, а також від сприймання складності завдання [18]. Згідно з Моралесом, самоефективність - це корисна характеристика студентів, яка може збільшити їхні зусилля і наполегливість [6, с. 324].

Недолік позитивної самоефективності і страх невдачі можуть перешкодити учням бути активними на заняттях, задавати питання і ставити перед собою завдання, що ще більше ускладнює навчання [15]. Л. Сандер і П. Сандерс упевнені, що на переконання учнів у своїй низькій самоефективності впливають негативні оцінки, відгуки вчителів, порівняння з однолітками та відгуки однолітків. Студенти з низькою самоефективністю мають низьку впевненість у своїх здібностях та можливостях і не проявляють активності у пізнавальній діяльності [16].

Д. Коркетт та її співавтори переконані: щоб підвищити самоефективність учнів, учителям треба iii оцінювати у кожного учня, використовуючи такі інструменти, як запитальники й опитування, щоб визначити сферу їхніх потреб, оскільки переконання у власній самоефективності впливають на успішність навчання [14].

Норвезьські вчені Скаалвік і Ранкін (1995р.) стверджують, що існує сильна позитивна кореляція між очікуваннями успіху і дійсними досягненнями. Очікування успіху є одним із проявів високої самоефективності [5, с. 325].

Г. Лефрансуа вважає, що висока самоефективність і позитивна самооцінка (самоповага) сприятливо впливають на досягнення учнів та їх сприйняття ситуацій. Переконаність в успіху в якійсь справі, завзятість суттєво впливають на вибір дій, на зусилля 3 досягнення бажаного результату [5, с. 124].

Як визначає С. Гончар, сучасному суспільству потрібні високоефективні особистості, які здатні адекватно оцінити власні можливості і результати своєї діяльності. Суб'єктивне ставлення до діяльності реалізується у спрямованості людини до своїх внутрішніх резервів, потенціалі розвитку, можливостях вибору засобів дій і побудови певної стратегії діяльності, поведінки і життя у цілому, що визначається самоефективністю особистості $[2$, с. 250$]$. 
А. Линенко розуміє самоефективність як важливий чинник, що визначає вибір особистістю продуктивних дій для успішного вирішення поставлених цілей, завдань. Услід за Д. Леонтьєвим особливу увагу в становленні зазначеного феномена вчена приділяє самосвідомості. Так, авторка розуміє професійну самоефективність майбутнього вчителя як складне, динамічне утворення особистості, що засноване на розвиненій педагогічній самосвідомості, розумінні вимог соціуму й усвідомленні свого місця у педагогічній дійсності, сформованій компетентності, наявності адекватної самооцінки, спрямованих на успішність здійснення професійної діяльності [6].

Психолог К. Бугакова відзначає, що суднових офіцерів треба навчати основам ефективної комунікації, формувати у них необхідні якості для успішного, комфортного, благополучного і добре налагодженого спілкування на борту [1].

Навички продуктивного спілкування необхідні судноводіям, перш за все, у ролі оператора-штурмана, який несе вахту на ходовому містку й отримує велику кількість інформації, прийом, обробка і передача якої є функціями комунікації.

3 огляду на вищезазначене, для успішного здійснення складної, багатопрофільної, багатофункціональної професійної діяльності морського офіцера, судноводія важливі і необхідні всі вищеприведені якості, тому що професійна діяльність судноводія здійснюється часто в небезпечних, суворих умовах відкритого океанського простору, проведення судна через складні вузькості, проливи серед великої скупченості суден різного тоннажу, катерів, джонок і т. п., наприклад у Південно-Китайському морі або у Середземному, складних умовах швартування тощо.

О. Погорєлов визначає самоефективність як упевненість людини в тому, що свої знання, вміння, навички, досвід, вироблені раніше в конкретному виді діяльності, він зможе застосувати в аналогічній діяльності в майбутньому і доб'ється при цьому успіху [8, с. 144].

Підводячи проміжний підсумок, підкреслимо, що сформована комунікативна самоефективність майбутніх судноводіїв заснована на впевненості у своїх силах і можливостях, професійних уміннях та навичках, розвиненій активності, що дає змогу ефективно комунікувати з різними суб'єктами спілкування: представниками іноземних морських портів, різних компаній, вести складну документацію; сприяє злагодженій роботі екіпажу, часто багатонаціонального.

У зв'язку з тим, що останні десятиріччя українські моряки працюють на суднах під іноземними прапорами, команди суден складаються
3 представників різних національностей, етносів, релігійних конфесій тощо. Тому, як підкреслює С. Смирнов, судноводієві необхідно мати навички 3 організації спілкування 3 представниками різного віку, різних національностей, конфесій: розуміти значення жестів іноземців, їхню міміку, тобто невербальні прояви, і не припускати того, що може визвати зворотну негативну реакцію $[10$, с. 80$]$.

Комунікативну самоефективність визначаємо як особистісне інтегральне утворення, що засноване на володінні курсантами - майбутніми судноводіями комунікативним потенціалом, обізнаністю, вміннями і навичками у контексті комунікації, які сприяють прояву компетентності у професійному спілкуванні, упевненості і продуктивності здійснення своїх професійних обов'язків у сфері професійної діяльності.

Компонентами комунікативної самоефективності майбутніх судноводіїв визначаємо: рефлексивний (самоідентифікація із судноводіями як еталонами професіоналізму, наявність адекватної самооцінки своїх дій у сфері професійного спілкування, усталена рефлексивна позиція); когнітивно-операційний (обізнаність у комунікативній сфері морської професійної діяльності, вміння, навички професійного спілкування); афективно-поведінковий (упевненість у можливості здійснення продуктивної комунікації у професійної діяльності, емоційність, активність, відповідальність, етнокультурна толерантність, здібність до саморегуляції та самопідкріплення) [3].

Морський фахівець із високим рівнем самоефективності відзначається активною поведінкою, цілеспрямованістю, постановкою конкретних цілей, здійснює самоконтроль стилю управління, спілкування зі своїми підлеглими і співробітниками, відзначається адекватною поведінкою, здатний до саморегуляції й успішно здійснює професійну діяльність.

Висновки. Таким чином, за останні роки з'явилася значна кількість психолого-педагогічних робіт, присвячених різним підходам до дослідження понять «самоефективність», «комунікативна самоефективність», що підтверджують необхідність їх формування у тих, хто навчається, для забезпечення результативності та успішності здійснення майбутньої професійної діяльності. Стійке усвідомлення майбутнього судноводія своєї комунікативної самоефективності сприяє впевненості в результативності досягнення поставлених професійних завдань. Тому сформовану комунікативну самоефективність розглядуємо як важливий чинник підвищення якості підготовки курсантів морських закладів вищої освіти до професійної діяльності. 


\section{ЛІТЕРАТУРА}

1. Бугакова Е.С. Формирование коммуникативной компетентности у курсантов морского профиля. Теория и практика общественного развития 2015. № 9. 252 с.

2. Гончар С.Н. Самоэффективность как профессиональное качество будущих педагогов-психологов. Педагогическое майстерство : материалы I Межд. науч. конф., г. Москва, апрель 2012 г. Москва : Буки-Веди, 2012. С. 250-253.

3. Дмитрищук Н.В., Линенко А.Ф. Комунікативна самоефективність майбутніх судноводіїв. Науковий вісник ПДПУ ім. К.Д. Ушинського. Педагогіка. 2019. Вип. 1(286). С. 65-70.

4. Кузьменко Г.В., Роменский О.М. Вестник Приамурского государственного университета им. Шолом-Алейхема 2015. № 1(18). С. 72-81.

5. Лефрансуа Г. Теории научения. Формирование поведения человека. Санкт-Петербург : Прайм-ЕВPOЗНАК, 2003. $278 \mathrm{c}$.

6. Лефрансуа Г. Прикладная педагогическая психология. Санкт-Петербург : Прайм-ЕВРОЗНАК, 2003. $416 \mathrm{c}$.

7. Линенко А.Ф. Професійна самоефективність як педагогічна проблема. Науковий вісник ПДПУ ім. К.Д. Уиинського. Педагогіка. 2019. Вип. 1(286). С. 66-68.

8. Немцев О.В., Иванова А.А., Бочарникова Г.Ю. Подготовка морских специалистов в вузе. Владивосток : Дальрыбвтуз. URL: https://cyberleninka.ru/article/n/podgotovka-morskih-spetsialistov-v-vuze.

9. Погорелов А.А. Самоэффективность как предиктор эффективного и безопасного поведения личности. Известия ЮФУ. Технические науки. 2012. № 4(129). С. 140-145.

10. Пузько В.И. Психологический аспект отбора успешных руководителей плавсостава. Сб. материалов уч-метод. семинара «Проблемы подготовки морских специалистов и пути их решения». Владивосток : МгУ, 2008. С. 46-64.

11. Смирнов С.В. Формування конкурентоздатності майбутніх судноводіїв у процесі професійної підготовки у морських закладах вищої освіти : дис. ... канд. пед. наук : 13.00.04. Одеса, 2018. 325 с.

12. Bandura. Self-Efficacy in Changing Societies / ed. A. Bandura. New York : Cambridge. University Press, 1995. P. 1-45.

13. Bandura, A. Self-efficacy: toward a unifying theory of behavioral change. Psychological Review. 1977. Vol. 84. P. 191-215.

14. Corkett, Julie; Hatt, Blaine; Benevides, Tina. Student and Teacher Self-Efficacy and the Connection to Reading and Writing. Canadian Journal of Education. 2011. Vol. 34 № 1. P. 65-98.

15. LaRose R. The Psychology of Interactive Media Habits. The Handbook of the Psychology of Communication Technology, John Wiley \& Sons, 2015. P. 365-383.

16. Sanders L., Sander P. Academic Behavioural Confidence: A comparison of medical and psychology students. Electronic Journal of Research in Educational Psychology. 13(4): December 2007. P. 633-649 URL: https://www.researchgate.net/publication/233747695.

17. Zimmerman B. Dedication: Albert Bandura. Contemporary Educational Psychology (October 1986), $11(4)$, p. 306.

18. Wigfield, A., \& Eccles, J. S. Expectancy-value theory of achievement motivation. Contemporary Educational Psychology, 25 (1), p. 68-72. URL: https://doi.org/10.1006/ceps.1999.1015.

\section{REFERENCES}

1. Bugakova E.S. (2015) Formirovaniye kommunikativnoy kompetentnosti u kursantov morskogo profilya [Formation of communicative competence among cadets of the marine profile]. Teoriya i praktika obshchestvennogo razvitiya [Theory and practice of social development]. No. 9. pp. 246-252. Retrieved from: https://cyberleninka.ru/article/n/formirovanie-kommunikativnoy-kompetentnosti-u-kursantov-vuza-morskogo-profilya.

2. Gonchar S.N. (2012) Samoeffektivnost' kak professional'noye kachestvo budushchikh pedagogov-psikhologov [Self-efficacy as a professional quality of future pedagogues-psychologists]. Pedagogical skill: materials of the 1st Int. scientific conference. M. : Buki-Vedi, 2012 . pp. 250-253.

3. Dmytryshchuk N.V., Linenko A.F. (2019) [Communicative self-efficacy of future navigators]. Scientific herald of the PDPU named after K. D. Ushinsky. Issue 1 (286). Series: Pedagogy. Odessa, pp. 65-70.

4. Kuzmenko V.V., Romensky A.V. (2015) Effektivnaya professional'naya kommunikatsiya moryakov zalog bezavariynoy raboty sudna [Effective professional communication of seafarers is a guarantee of trouble-free operation of the vessel]. Bulletin of the Amur State University. Sholem Aleichem. Scientific and educational journal. Birobidzhan: Amur State University named after Sholem Aleichem, No. 1.pp. 72-81. 
5. Lefrancois G. Learning theories. (2003) Teorii naucheniya. Formirovaniye povedeniya cheloveka [Human Behavior Formation]. SPb : Prime. EVROZNAK.

6. Lefrancois G. (2003) Prikladnaya pedagogicheskaya psikhologiya [Applied educational psychology]. $\mathrm{SPb}$. : Prime. EVROZNAK.

7. Linenko A.F. (2019) Profesiyna samoefektyvnist' yak pedahohichna problema [Professional self-efficacy as a pedagogical problem]. Scientific herald of PDPU named after K.D. Ushinsky. 1 (286). Series: Pedagogy. Odessa, pp. 66-68.

8. Nemtsev O.V., Ivanova A.A., Bocharnikova G.Yu. (2009) Podgotovka morskikh spetsialistov v vuze [Electronic resource] Training of marine specialists at the university. Vladivostok: Dalrybvtuz. Retrieved from: https://cyberleninka.ru/article/n/podgotovka-morskih-spetsialistov-v-vuze.

9. Pogorelov A.A. (2012) Samoeffektivnost' kak prediktor effektivnogo i bezopasnogo povedeniya lichnosti [Self-efficacy as a predictor of effective and safe behavior of the individual]. Izvestia SFedU. Rostovon-Don, Technical sciences, No. 4 (129).

10. Puzko V.I. (2008) Psikhologicheskiy aspekt otbora uspeshnykh rukovoditeley plav sostava [Psychological aspect of the selection of successful leaders of the floating structure] Materials of seminar "Problems of training marine specialists and ways to solve them." - Vladivostok: Publishing house of Moscow State University.

11. Smirnov S.V. (2018) Formuvannya konkurentozdatnosti maybutnikh sudnovodiyiv u protsesi profesiynoyi pidhotovky u mors'kykh zakladakh vyshchoyi osvity [Formation of competitiveness of future shipowners in the process of professional training in maritime institutions of higher education]: dis. ... cand. ped. Sciences: 13.00.04. Odessa.

12. A. Bandura (1995) Self-Efficacy in Changing Societies. New York : Cambridge. University Press, 1995. pp. 1-45.

13. Bandura, A. (1977) Self-efficacy: toward a unifying theory of behavioral change. Psychological Review. 1977. Vol. 84. pp. 191-215.

14. Corkett, Julie; Hatt, Blaine; Benevides, Tina. Student and Teacher Self-Efficacy and the Connection to Reading and Writing (2011). Canadian Journal of Education, v. 34 n. 1. P. 65-98.

15. LaRose R. The Psychology of Interactive Media Habits (2015). The Handbook of the Psychology of Communication Technology, John Wiley \& Sons. P. 365-383.

16. Sanders L., Sander P. (2007). Academic Behavioural Confidence: A comparison of medical and psychology students. Electronic Journal of Research in Educational Psychology 13(4). P. 633-649 Retrieved from: https://www.researchgate.net/ publication/ 233747695.

17. Zimmerman B. (October 1986). Dedication: Albert Bandura. Contemporary Educational Psychology, 11 (4).

18. Wigfield, A., \& Eccles, J.S. (2000). Expectancy-Value theory of achievement motivation. Contemporary Educational Psychology, 25(1). P. 68-72. Retrieved from: https://doi.org/10.1006/ceps.1999.1015. 